\title{
Discussies in crisistijd
}

\author{
Maureen Limpens
}

Published online: 11 May 2020

(C) Bohn Stafleu van Loghum is een imprint van Springer Media B.V., onderdeel van Springer Nature 2020

Op het moment van schrijven van deze visie (6 april) zitten we middenin de coronacrisis. De NVvP werkt zich uit de naad om alle leden voortdurend te voorzien van het meest recente nieuws. Dat gaat zowel over 'hoe blijven de praktijken financieel overeind?' als over 'hoe te handelen in deze tijd om besmetting met het coronavirus te voorkomen?'.

Wat betreft het financiële plaatje is er op het moment van schrijven nog veel onduidelijk. Van welke regelingen kunnen podotherapeuten nu wel of niet gebruikmaken: aanspraak maken op de $€ 4.000$ uit het noodfonds of wachten op de regeling die voorbereid werd door zorgverzekeraars. Hoe zit het met de vergoeding van de gecontracteerde zorg en de vergoeding van de niet-gecontracteerde zorg? Moet er voor het ene deel misschien toch een beroep op het noodfonds worden gedaan en voor het andere deel op de regeling van de zorgverzekeraars? Of sluit het een het ander misschien uit? Ten aanzien van de financiën zal bij het verschijnen van deze Podosophia voor de korte termijn al wel meer duidelijk zijn. De consequenties voor de lange termijn zullen echter ook nu nog onduidelijk zijn.
Wat betreft de behandelopties wordt er op social media volop gediscussieerd over podotherapeutische zorg op afstand - met videoconsulten en het opsturen van schuimdozen. De discussie spitst zich toe op hoe je de kwaliteit hoog kan houden als jij de patiënt niet zelf kan palperen en als de patiënt zelf bepaalde handelingen moet uitvoeren. Hoe zorg je ervoor dat de patiënt op de juiste manier in de schuimdoos stapt, hoe lees je een gangpatroon via beeldbellen, maar ook, hoe zit het met de veiligheid van de verbinding etc. Voor de ene podotherapeut is deze ontwikkeling, gezien de kwaliteitsvraag, een nachtmerrie. Voor de ander is het een 'pioniers'vraag. De komende tijd zal, vermoed ik, verder onderzocht worden of en zo ja, welke patiënten wel en welke niet via een videoconsult gezien kunnen worden, onder welke voorwaarden en hoe de kwaliteit dan geborgd wordt. En dan hebben we natuurlijk nog de discussie over de 'COVID-19tenen', zijn de huidafwijkingen bij de tenen inderdaad een voorbode van een COVID-19-besmetting? De tijd zal het leren.

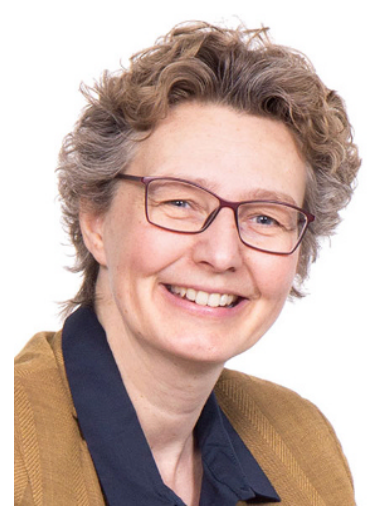

Maureen Limpens, hoofdredacteur 